\title{
LOGISZTIKAI KOMPETENCIÁK ÉS FEJLESZTÉSI LEHETŐSÉGÜK AZ OKTATÁSBAN
}

A logisztika egyes területein dolgozó munkavállalók kompetenciaigényével viszonylag kevés kutatás foglalkozik. E hazai és a nemzetközi kutatások összeszedték azokat az „általános” és speciális kompetenciákat, amelyeket a munkáltatók elvárnak. A szerzők ebben a cikkben a kompetenciákat a logisztikai képzés oktatásmódszertanával kötik össze. Azt vizsgálják, hogy mely kooperatív oktatási módszerek mennyire képesek a kompetenciák fejlesztésére. Kutatásukhoz online kérdőíves felmérést használtak, amelyet két célcsoport, a logisztikai ügyintézők képzésére szolgáló logisztikai OKJ-képzés diákjai, illetve ellátásilánc-menedzsment mesterszakos egyetemi hallgatók töltöttek ki.

Eredményeik alapján az OKJ-s hallgatók többre tartják a kooperatív módszereket, mint a mesterszakos hallgatók, pedig az ezek által támogatott kompetenciákra az utóbbi csoportnak nagyobb szüksége lenne. Elgondolkodtató eredmény, hogy az online alkalmazásokat az egyetemi hallgatók a lehetséges eszközök közül a legnegatívabban értékelték. Ez utóbbinak külön is utánajártak.

Kulcsszavak: kompetenciaelvárások, kompetenciák fejlesztése, logisztika, oktatás, képzés, kooperatív módszerek, hatékonyság

$\mathrm{M}$ agyarország Európa közepén található, melynek következményeként számos fontos logisztikai útvonal halad át rajta és több nemzetközi logisztikai cég is jelen van szolgáltatásaival. Ráadásul a magyarországi termelőszektor maga is növekedik: a KSH 2001-2017 közötti éves idősoros folyó áras adatai alapján a 2001-es termelés értéke 12.589 Mrd Ft-ról 2017-re 30.578 Mrd Ft-ra nőtt, csak a válság időszakában volt némi visszaesés. (http://www. $\mathrm{ksh} . \mathrm{hu} / \mathrm{docs} / \mathrm{hun} / \mathrm{xstadat} / \mathrm{xstadat}$ eves/i_oia002.html). Így könnyen belátható, hogy a logisztika és az ellátásilánc-menedzsment területén egyre nagyobb igény van jól felkészült szakemberekre. De milyen képességekkel kell ezeknek a szakembereknek rendelkezniük?

A gazdaság, a technológia és a társadalom gyorsuló fejlődésével, a komplex feladatok gyarapodásával, a digitalizáció és az internet általánossá válásával az információk, tények gyorsan elavulnak. Ezért a mai összetett és kölcsönös függőségekkel átszőtt világban a szakma tartalmi ismeretén túl a helytálláshoz az ún. puha képességek fejlesztésére is figyelmet kell fordítani a képzések során. Ezek közé tartozik például a komplex gondolkodásmód, a fejlett kommunikációs készségek és a társas helyzetekben való együttmüködés (Mihalkovné, 2014). Ezek olyan képességek, amelyeket a gépek még egy ideig nem tudnak helyettesíteni. Más szerzők is arra jutottak, hogy nagyon sokrétü az a kompetenciahalmaz, amivel a mai logisztikai és ellátásilánc-menedzsereknek rendelkezniük kell (Thai et al., 2011; Derwik et al., 2016, 2017; Flöthmann \& Hoberg, 2017). Hoberg és szerzőtársai (2014) egyenesen tízpróbázóknak, „decathletes” nevezi őket.

Korábbi kutatások (Patóné, 2006; Keller, 1999; Gibson et al., 1998; Myers, 2004) részletesen, a logisztikai szakma néhány kitüntetett feladatkörére vonatkozóan is feltárták, hogy logisztikai szakembereknek milyen kompetenciákkal kell rendelkezniük, hogy a vállalat sikeressé és versenyképessé váljon, és azt fenn is tartsa. Kutatásunkban ezeket a részletes kompetenciakritériumokat alapul véve kérdeztük meg a logisztika területein közép- és felsőfokú oktatásban (OKJ és MSc) részt vevő hallgatók véleményét az oktatás során tapasztalt kooperatív módszerek ismertségéről és hasznosságáról. Arra voltunk kíváncsiak, hogy szerintük a potenciális munkáltatók milyen kompetenciákat várnak el tőlük.

Fontos látni, hogy a képzés különböző szintjein megjelenő tanulók hogyan vélekednek az egyes módszerek hasznosságáról. Vajon felfedezhető-e számottevő különbség az OKJ-s és a mesterszintű tanulók között? Mivel a később betöltendő munkahelyi pozícióval járó tevékenységi, felelősségi körök, szakmai elvárások jellemzően különbözni fognak, ez eltérő kompetenciák fejlesztését, és így várhatóan eltérő módszerek alkalmazását igényli a képzés során (McKinnon et al., 2017). Például az ügyintézőnek nagy valószínűséggel nem, míg egy vezetőnek kell majd a munkája során olyan döntéseket hoznia, melyhez a komplex látásmód és a hatékony döntéshozási képesség kiemelten fontos fejlesztendö terület a mesterszintü képzésben.

A kutatás fontosságát támasztja alá, hogy bár a logisztikai vezetőkkel kapcsolatos elvárásokról nemzetközileg még akad szakirodalom (Thai et al., 2011; Derwik et al., 2016, 2017; Flöthmann \& Hoberg, 2017; Hoberg et al., 2014), a kezük alatt dolgozó szakemberekröl, például termeléstervezőkről, operatív beszerzőkről, logisztikai ügyintézőkről azonban már nincs, Magyarországon pedig egyáltalán nincs friss irodalom. Pedig a gazdaságban végbemenő változások, a tudomány és az üzleti élet részéről jelentkező homályos kritériumok és elvárások szükségessé teszik a rendelkezésre álló munkaerő-piaci elvárásokkal kapcsolatos információk frissítését.

Ráadásul a szakirodalomban egyáltalán nem lelhető fel a jelen tanulmányhoz hasonló - tanulói véleményre irányuló - kutatás. Pedig nemcsak a munkáltatók elvárásai, hanem a tanulók elvárásokkal kapcsolatos elképzelései is 
befolyásolják, hogy képzésüket mennyire tartják hasznosnak. Minél inkább összhangban van a képzés az elvárásokkal, annál nagyobb energiát hajlandóak belefektetni a diákok a tanulásba, ami a képzés hatékonyságának egyik alapvető feltétele. A jelen kutatás felhasználható majd további kutatások esetleges kiindulópontjaként.

A cikkben először bemutatjuk az egyes logisztikai alrendszerek kompetenciaelvárásait korábbi kutatások eredményei alapján. Majd a kompetenciákat fejlesztő módszerekről nyújtunk áttekintést. Utána rátérünk a kutatásra, ahol kérdőív segítségével, majd néhány eredmény verifikálásával megvizsgáljuk, vajon van-e, és ha igen, miért van eltérés az egyes módszerek megítélésében az OKJ-sek és a mesterszintű hallgatók között. Végül összefoglalással és következtetések levonásával zárjuk cikkünket.

\section{A logisztikai kompetenciákról általában}

Az utóbbi 30 évben mélyreható változás megfigyelhető a logisztika és az ellátási lánc területén, ami a logisztikai területen dolgozóktól elvárt képességek halmazát is megváltoztatta. Ma már egy sikeres logisztikai vezetőnek üzleti, logisztikai és menedzsmentkészséggel és -tudással egyaránt rendelkeznie kell (Thai et al., 2011). A naponta megoldandó összetett feladatok sokasága komplex látásmódot és gondolkodásmódot, különböző üzleti területeken, a stratégiai döntéshozatalban, a kommunikációban, a vezetésben, az interkulturális készségekben, valamint a fejlett analitikai és informatikai készségek területén szerzett jártasságot kíván (Flöthmann \& Hoberg, 2017). Ezen elvárások szerint a ma logisztikai vezetöit, akár tízpróbázóknak "decathletes" is nevezhetjük Hoberg és szerzőtársai (2014) szerint.

Derwik és szerzőtársai $(2016,2017)$ kutatásukban a logisztika és ellátási lánc egyes területein dolgozó menedzserek által használt kompetenciákat tárták fel - megfigyeléssel és interjúkkal (a triangulációs technikát alkalmazva) - és vetették össze korábbi kutatások eredményeivel. Eredményképpen a kompetenciákat öt nagy kategóriába sorolták. Ezek a következők (zárójelben az egyes kompetenciacsoportok használatának mértéke látható a menedzserek napi tevékenysége, döntéshozatala során):

- üzleti kompetenciák (dinamikus tudatosság, üzleti és érintett menedzsment) (megfigyelések 30-40\%),

- általános kompetenciák (kommunikációs és kognitív képességek) (20-30\%),

- viselkedésbeli kompetenciák (intraperszonális és interperszonális) (15-30\%),

- ellátásilánc-menedzsment szaktudás (ellátásiláncmenedzsment tudásterületek és alkalmazott elemzések) $(0-5 \%)$,

- funkcionális kompetenciák (technológia, adminisztratív rutinok) (5-20\%).

A vizsgálat alátámasztja, hogy a konkrét szakismeretek a legkevésbé fontosak a vezetők napi gyakorlatában. Bár a szerzők felhívják a figyelmet, hogy ezen ismeretek nélkül senki nem válhatna sikeres logisztikai vezetővé, mégis egyértelmü, hogy az oktatásban a puha kompetenciák fejlesztése elengedhetetlenné vált.

McKinnon és szerzőtársai (2017) túllépnek az általános menedzseri megközelítésen. Kutatásukban a munka- vállalói csoportokat négy különböző kategóriába (operatív, adminisztratív, müszak- vagy csoportvezetők, illetve logisztikai vezetők) osztják, hogy a készség- és képzési követelményeiket külön lehessen elemezni.

Lutz és Birou (2013) az iparág és az oktatás közötti szorosabb együttmüködésre sarkallnak, hogy hasznosabb kurzusokat lehessen tartani. Elméleti oktatás (research base) helyett több esettanulmány alkalmazását szorgalmazzák, hogy releváns képességeket fejleszthessenek az oktatási intézmények a piac számára. Hoek 2001-ben végzett kutatása szerint - a később bemutatott - moderációs módszer is segíti a kurzusok piaci és szakmai relevanciájának, valamint a hallgatók kutatási képességeinek növelését.

A képességek, kompetenciák az ismereteket/tudást, attitűdöket és a készségeket egyaránt magukba foglalják (Losonci et al., 2018). Sauber és szerzőtársai (2008) szerint a kompetencia a tanulási folyamat eredményének megnyilvánulása, amely lehet valaminek a felismerése, valamely ismeretnek a tudása, vagy egy készség vagy képesség, amely alkalmassá teszi az egyént bizonyos tevékenységek elvégzésére. Ugyanakkor más megközelítés szerint a kompetenciák rendszerén belül megkülönböztetünk személyes, kognitív, szociális és speciális kompetenciákat (Nagy, 2000).

\section{Kompetenciaelvárások az egyes logisztikai alrendszerekben}

„A logisztikai rendszer az anyagi áramlások és készletek, valamint a rájuk vonatkozó információk és irányítási struktúrák rendszere" (Chikán, 2017, p. 393). A logisztikai folyamat három fö szakasza/területe, amelyek külön-külön vevőkiszolgálási ciklusként értelmezhetők, a beszerzés (amikor a beszerző a vevő), a termelésellátás (a termelés a vevő) és a disztribúció/értékesítés (a külső vevő a vevő) (Chikán, 2017; Demeter et al., 2009). Az egyes ciklusok közötti szakadási pontokat - amikor nem áramlik az anyag - azaz készletek halmozódnak fel - az 1. ábrán raktározásként tüntetjük fel. A következőkben áttekintjük az egyes alrendszerek munkavállalóival szemben támasztott kompetencia elvárásokat.

\section{1. ábra A logisztika fő területei (saját szerkesztés)}

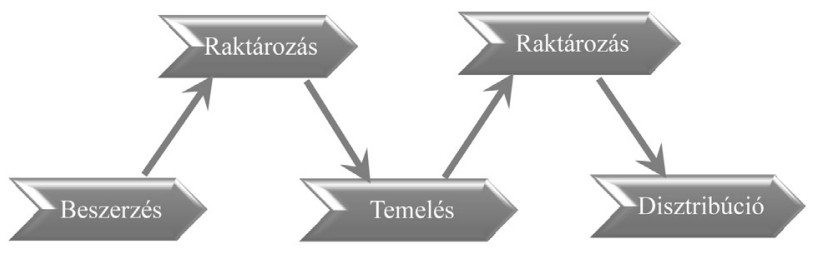

Az 1. ábra kapcsán megjegyezzük, hogy az inverz logisztika is fontos területe a logisztikai rendszernek, de egyrészt a benne elvégzendő tevékenységek egybeesnek a logisztika többi területével, másrészt az elemzett források sem foglalkoznak vele külön (Chikán, 2017 is csak egy külön bekezdést ír róla).

Mielött azonban a részletekbe merülnénk, látni kell, hogy a logisztika bármely területén tevékenykedő cég vagy alkalmazott akkor végzi jól a munkáját, ha a fogyasztónak értéket teremt. A vállalatok ezért úgy határozzák meg elvárásaikat munkavállalóikkal szemben, hogy a munkavállalók önálló- 
an, akár kontroll nélkül is megfeleljenek e kritériumoknak. Számos olyan logisztikai munkakör létezik ugyanis, ahol lehetetlen közvetlen vezetői ellenőrzést gyakorolni (soför, ügyfélszolgálat, árukiszedés stb.). Ha nincs direkt ráhatás, akkor is megbízható és szakmailag kifogástalan munkát kell végeznie a beosztottnak, ezért rendkívül fontos a kiválasztás.

A tényleges teljesítményt viszont számtalan tényező befolyásolja, az attitüd, a képességek, a készségek, a szaktudás, a munkatapasztalat stb. Egy vállalat számára a munkavállaló értékét az érzékelt munkateljesítmény, a vállalati hierarchiában elfoglalt hely és különböző elemek léte vagy hiánya adja. Ezek feltérképezésével foglalkozik Myers és szerzőtársai (2004) kutatása, akik középvezetői szintig százötvenhét cég vezetőjének megkérdezésével vizsgálták a logisztikai szakemberek teljesítményét. Megállapították, hogy az alsóbb szinteken - középszintig - az iskolázottságnak és a logisztika területén szerzett korábbi munkatapasztalatnak nincs hatása a munkateljesítményre, ugyanakkor a szaktudásnak, készségeknek és képességeknek nagymértékü a befolyása. A legfontosabb képességeket 4 kategóriába sorolták: problémamegoldó, szociális, döntéshozási és időmenedzselési képesség. A problémamegoldás képessége magában foglalja az analitikus gondolkodást, kreativitást. A szociális képességek, készségek jelenítik meg az interperszonális kapcsolatokat, stressztürést, vezetést, csapatépítést, kommunikációt. A döntéshozási képességekhez sorolják az önbizalmat, magabiztosságot, új ismeretekre való nyitottságot, gyors analizálás képességét, intuitív képességet, objektivitást. Érdekes lehet, hogy az idömenedzselési készséghez sorolják nemcsak a határidők betartását, hanem a fontossági sorrend meghatározását is.

Mindamellett, hogy a képességek, készségek csoportosításával számos további szakirodalom (pl. Ballér et al., 2003.: általános és speciális képességek, vagy Juhász, 2004.: kemény és puha képességek) foglalkozik, Myers-ék csoportosítását vesszük alapul a továbbiakban, és az általuk felállított keretrendszerbe fogjuk a tárgyalt kompetenciákat beilleszteni.

Visszakanyarodva a logisztika egyes területein meghatározott kompetenciákhoz, a Council of Logistics Management (CLM) már az 1990-es években érzékelte a megfelelő készségekkel és képességekkel rendelkező munkaerő fontosságát a logisztika területén, ezért a Mississippi Egyetemmel közösen egy széles körü kutatásba kezdtek. Céljuk a munkakörök, a munkaköri feladatok és az azokhoz szükséges kompetenciák, illetve az oktatással kapcsolatos elvárások feltárása volt. Az eredményeket 1999-ben publikálták (Keller, 1999). Bár a CLM által végzett kutatásban sokkal inkább az elvárt ismeretek, mint a kompetenciák jelentek meg, melyeket a jelölt a képzés során sajátított el, mi itt csak a kompetenciákkal foglalkozunk.

Az itthon jellemző elvárások ismertetéséhez az egyetlen ilyen jellegü kutatást vesszük alapul, melyet 2006ban Pató Gáborné Szűcs Beáta készített „Kompetenciák, feladatok logisztikai rendszerekben" címmel doktori disszertációként. Munkája során dokumentumelemzési technika segítségével az összegyüjtött hatszáztizenkettő munkaköri leírásból hetvenegy kompetenciát határozott meg. Mindezek mellett nem szabad megfeledkezni a rejtett, evidenciaként elvárt kompetenciákról, melyek nem szerepeltek a munkaköri leírásokban, ugyanakkor megjelentek követelményként a jelentkezővel szemben. Későbbiekben született meg - nagyon hasonló módon - Karcsics Éva (2012) vezetők kompetenciaelvárásaival kapcsolatos kutatása is, amelyben a korábban vázolt Myers (2004) és szerzőtársai által megállapított eredmények - miszerint az iskolázottságnak, és a logisztika területén szerzett korábbi munkatapasztalatnak nincs ráhatása a munkateljesítményre, ugyanakkor a szaktudásnak, készségeknek és képességeknek nagymértékü a befolyása - a magyar munkakörnyezetben megdőltek. Karcsics kutatása szerint a logisztika területére jelentkező vezetőktől az álláshirdetések 34\%-a elvárásként fogalmazza meg a szakmai gyakorlatot.

A korábban már említett Derwik és szerzőtársai (2016) kutatásukban viszont arra a következtetésre jutottak, hogy a menedzserek inkább „üzleti általános” és ,viselkedéssel kapcsolatos” kompetenciájukat használják munkájuk során, mint a logisztika és ellátási lánc területén megszerzett tapasztalataikat, és attól függően, hogy ezeket hogyan kombinálják, érnek el a vezetők szinergikus hatásokat. Tehát a gyakorlatban alkalmazott kompetenciák szintje túlmutat az egyéni kompetenciák összegén.

A következőkben az egyes logisztikai területeken elvárt kompetenciákat mutatjuk be részletesen a nemzetközi (Keller, 1999; Gibson et al., 1998) és az itthoni (Patóné, 2006) kutatások alapján. A jobb áttekinthetőség érdekében a 2. és 3. ábrában foglaltuk össze a két kutatás által feltárt logisztikaspecifikus kompetenciákat. A leggyakrabban előforduló általános kompetenciákat a melléklet tartalmazza. 
2. ábra Keller (1999) alapján elvárt specifikus kompetenciák a logisztika egyes területein (saját szerkesztés)

\begin{tabular}{|c|c|c|}
\hline $\begin{array}{c}\text { Beszerzés területén } \\
\text { elvárt kompetenciák } \\
\text { Mississippi } \\
\end{array}$ & $\begin{array}{c}\text { Raktározás területén } \\
\text { elvárt kompetenciák } \\
\text { Mississippi }\end{array}$ & $\begin{array}{c}\text { Termelés területén } \\
\text { elvárt kompetenciák } \\
\text { Mississippi } \\
\end{array}$ \\
\hline \multirow{2}{*}{$\begin{array}{l}\text { kommunikációs } \\
\text { technikák alkalmazása }\end{array}$} & raktári ellenör: & döntéshozási képesség \\
\hline & betanítási képesség & ellenőrzési \\
\hline \multirow{3}{*}{$\begin{array}{l}\text { konfliktus- és } \\
\text { stressz- kezelési } \\
\text { technikák alkalmazása }\end{array}$} & ellenőrzési képesség & fejlesztési \\
\hline & (teljesítményértékelés), & \multirow{2}{*}{$\begin{array}{l}\text { időgazdálkodási } \\
\text { képesség }\end{array}$} \\
\hline & kommunikációs készség & \\
\hline \multirow{8}{*}{$\begin{array}{l}\text { találkozók } \\
\text { levezetésének } \\
\text { képessége }\end{array}$} & motiválási képesség & \multirow{2}{*}{$\begin{array}{l}\text { kiváló kommunikációs } \\
\text { készség }\end{array}$} \\
\hline & stressz-menedzsment & \\
\hline & szervezési, & \multirow[t]{6}{*}{ motivációs készség } \\
\hline & $\begin{array}{l}\text { időgazdálkodási } \\
\text { képesség }\end{array}$ & \\
\hline & $\begin{array}{l}\text { technikai eszközök } \\
\text { felhasználói szintü } \\
\text { kezelése }\end{array}$ & \\
\hline & $\begin{array}{l}\text { raktár vezetőtől ezeken } \\
\text { felül még }\end{array}$ & \\
\hline & döntéshozási képesség & \\
\hline & prezentációs készség & \\
\hline
\end{tabular}

\begin{tabular}{|l|}
\hline $\begin{array}{c}\text { Disztribúció területén } \\
\text { elvárt kompetenciák } \\
\text { Mississippi }\end{array}$ \\
\hline ellenőrzési \\
\hline fejlesztési \\
\hline $\begin{array}{l}\text { hatékony döntéshozási } \\
\text { képesség }\end{array}$ \\
\hline időgazdálkodási készség \\
\hline $\begin{array}{l}\text { kiválasztási és toborzási } \\
\text { képesség }\end{array}$ \\
\hline kommunikációs készség \\
\hline oktatási készség \\
\hline $\begin{array}{l}\text { vezetői, irányítói } \\
\text { készség }\end{array}$ \\
\hline
\end{tabular}

\begin{tabular}{|l|}
\hline $\begin{array}{c}\text { Vállalaton belüli átfogó } \\
\text { logisztikához köthető } \\
\text { kompetenciák }\end{array}$ \\
\hline Logisztikai felső vezetők \\
\hline $\begin{array}{l}\text { logisztikai szervezet } \\
\text { felépítésének, } \\
\text { fenntartásának és } \\
\text { fejlesztésének képessége }\end{array}$ \\
\hline $\begin{array}{l}\text { megfelelő emberek } \\
\text { kiválasztása, fejlesztése, } \\
\text { motiválása, ellenőrzése, }\end{array}$ \\
\hline csapatépítési képesség \\
\hline $\begin{array}{l}\text { kommunikációs-, } \\
\text { prezentációs készség }\end{array}$ \\
\hline $\begin{array}{l}\text { döntéshozási módszerek és } \\
\text { technikák }\end{array}$ \\
\hline Ellátásilánc-menedzser \\
\hline átfogó látásmóddal \\
\hline projektvezetési ismeretek, \\
\hline $\begin{array}{l}\text { kommunikációs és előadói } \\
\text { készség }\end{array}$ \\
\hline szervezöi készség \\
\hline $\begin{array}{l}\text { a hatékony döntéshozás } \\
\text { képessége }\end{array}$ \\
\hline stressz-, konfliktuskezelés \\
\hline
\end{tabular}

3. ábra Patóné (2006) alapján elvárt specifikus kompetenciák a logisztika egyes területein (saját szerkesztés) ${ }^{1}$

\begin{tabular}{|c|c|c|c|}
\hline $\begin{array}{l}\text { Beszerzés } \\
\text { területén } \\
\text { elvárt } \\
\text { kompeten- } \\
\text { ciák }\end{array}$ & $\begin{array}{l}\text { Raktározás } \\
\text { területén } \\
\text { elvárt } \\
\text { kompeten- } \\
\text { ciák }\end{array}$ & \multirow{3}{*}{$\begin{array}{l}\text { Szállítás, } \\
\text { anyag- } \\
\text { mozgatás } \\
\text { területén } \\
\text { elvárt } \\
\text { kompeten- } \\
\text { ciák }\end{array}$} & \multirow[t]{2}{*}{$\begin{array}{c}\text { Vállalaton } \\
\text { belüli átfogó } \\
\text { logisztiká- } \\
\text { hoz köthető } \\
\text { kompeten- } \\
\text { ciák }\end{array}$} \\
\hline \multirow{2}{*}{$\begin{array}{l}\text { átfogó } \\
\text { látásmód } \\
\end{array}$} & állóképesség, & & \\
\hline & \multirow{2}{*}{$\begin{array}{l}\text { alkalmazkodó } \\
\text { képesség }\end{array}$} & & \multirow{2}{*}{$\begin{array}{l}\text { információ- } \\
\text { kezelés }\end{array}$} \\
\hline \multirow{2}{*}{$\begin{array}{l}\text { csapatépítési } \\
\text { képesség }\end{array}$} & & \multirow{2}{*}{$\begin{array}{l}\text { érzelmi } \\
\text { terhelhetőség }\end{array}$} & \\
\hline & \multirow{2}{*}{$\begin{array}{l}\text { ápolt, jó } \\
\text { megjelenés }\end{array}$} & & \multirow{2}{*}{$\begin{array}{l}\text { kezdeményezö } \\
\text { készség }\end{array}$} \\
\hline ellenőrzés & & \multirow{2}{*}{$\begin{array}{l}\text { müszaki } \\
\text { érzék }\end{array}$} & \\
\hline \multirow{2}{*}{$\begin{array}{l}\text { felelősség- } \\
\text { tudat }\end{array}$} & \multirow{2}{*}{$\begin{array}{l}\text { áttekintő } \\
\text { képesség }\end{array}$} & & \\
\hline & & & \multirow{2}{*}{$\begin{array}{l}\text { logikus } \\
\text { gondolkodás }\end{array}$} \\
\hline \multirow{2}{*}{$\begin{array}{l}\text { kifejező } \\
\text { készség }\end{array}$} & extrovertáltság & & \\
\hline & figyelem & & $\begin{array}{l}\text { magabiztos } \\
\text { fellépés }\end{array}$ \\
\hline $\begin{array}{l}\text { kockázatvál- } \\
\text { lalási készség }\end{array}$ & konfl & & \multirow{2}{*}{$\begin{array}{l}\text { minőségtuda- } \\
\text { tosság }\end{array}$} \\
\hline \multirow{3}{*}{$\begin{array}{l}\text { komplex } \\
\text { gondolkodás- } \\
\text { mód }\end{array}$} & & & \\
\hline & $\begin{array}{l}\text { KovetKeze- } \\
\text { tesség }\end{array}$ & & motiváltság \\
\hline & közvetlenség & & \multirow{2}{*}{$\begin{array}{l}\text { munka- } \\
\text { szervező } \\
\text { képesség } \\
\end{array}$} \\
\hline $\begin{array}{l}\text { tárgyaló } \\
\text { képesség }\end{array}$ & \multirow{2}{*}{$\begin{array}{l}\text { megoldó } \\
\text { képesség, } \\
\text { módszeresség }\end{array}$} & & \\
\hline \multirow{3}{*}{$\begin{array}{l}\text { vállalati } \\
\text { szinten való } \\
\text { gondolkodás- } \\
\text { mód }\end{array}$} & & & $\begin{array}{l}\text { önálló } \\
\text { munkavégzés }\end{array}$ \\
\hline & rendszeretet & & rugalmasság \\
\hline & szakmai & & \multirow{3}{*}{$\begin{array}{l}\text { szervezet- } \\
\text { tudatosság }\end{array}$} \\
\hline \multirow{2}{*}{$\begin{array}{l}\text { vevő- } \\
\text { orientáltság }\end{array}$} & rátermettség & & \\
\hline & udvariasság & & \\
\hline
\end{tabular}

A 2. és 3. ábra beszerzés oszlopait összevetve (Patóné, 2006; Keller, 1999) két megállapítás tehető: 1) sokkal részletesebben határozta meg Patóné a beszerzéssel kapcsolatos kompetenciák listáját, 2) számos közös elem megtalálható a két listában: ilyenek a kommunikációs technikák alkalmazása és a kifejező készség, illetve a találkozók levezetésének képessége és a tárgyaló képesség kompetenciája.

A termelés területén szükséges kompetenciákkal csak a nemzetközi kutatás foglalkozik (Keller,1999; Gibson et al., 1998).

Itthon a raktározás területén sikerült összegyüjteni a legtöbb „megfogalmazott” kompetenciát. Érdekesség, hogy olyan kompetenciák is megjelennek itt, mint például az udvariasság, az extrovertáltság, a következetesség, a rendszeretet, melyekröl az olvasóban joggal merülhet fel a kérdés, hogy biztosan a kompetenciák körébe tartoznak-e. A nemzetközi kutatásban munkakörökhöz rendelték a feladatköröket, majd a szükséges kompetenciákat. Vezetői szintü munkakörök raktározás területén a raktári ellenőr és a raktárvezető.

Patóné kutatása szerint a szállitás és anyagmozgatás területére érdekes módon csak két specifikus kompetenciaelvárás a jellemző, természetesen számtalan általánosan elvárt kompetencia mellett (ld. melléklet).

A vállalaton belüli átfogó logisztikával foglalkozó vezetőnek széles körű információval, szaktudással, ismerettel, tapasztalattal, gyakorlattal és számtalan kompetenciával kell rendelkeznie, hogy sikeres és eredményes legyen, hiszen az összes eddig tárgyalt alrendszerről és azok össze-

\footnotetext{
${ }^{1}$ Patóné a disztribúció helyett a szállítás és anyagmozgatás kifejezést használja kutatásában. Érdemes észrevenni, hogy a 2. ábra tágabban, ellátásiláncfolyamatként, a 3. ábra végrehajtási folyamatként közelíti a logisztikát. Valószínűleg ebből is adódik az eltérő szóhasználat.
} 
függéseiről kell átfogó képpel bírnia. A CLM-kutatás (2. ábra) két felsővezetői munkakört - logisztikai felső vezetö, ellátásilánc-menedzser - azonosított a hozzá tartozó munkaköri leírással és feltételként azonosított kompetenciákkal.
A több alrendszerben is megjelenő kompetenciákat kigyűjtöttük a két kutatásból és besoroltuk őket a Myers (2004) által meghatározott négy fő kompetencia alá. Ezt a csoportosítást tartalmazza az 1. táblázat.

1. táblázat Kompetenciák csoportosítása Myers (2004) szempontjai alapján

(dőlt: Patóné kutatásában minden területen elvárt; vastag: mindkét kutatásban megjelenik; a zárójeles x arra utal, hogy az összegzésnél az adott szempontot egyszer már figyelembe vettük)

\begin{tabular}{|c|c|c|c|c|c|c|}
\hline Kutatás & & Képességek csoportjai & $\begin{array}{l}\text { probléma- } \\
\text { megoldó }\end{array}$ & $\begin{array}{l}\text { Szoci- } \\
\text { ális }\end{array}$ & $\begin{array}{l}\text { döntés- } \\
\text { hozási }\end{array}$ & $\begin{array}{l}\text { időme- } \\
\text { nedzselési }\end{array}$ \\
\hline \multirow{17}{*}{$\begin{array}{l}\text { Patóné (2006) féle kom- } \\
\text { petenciák: } 5+12\end{array}$} & 1 & csapatban történö munkavégzés & & $\mathrm{x}$ & & \\
\hline & 2 & együttmüködési képesség & & $\mathrm{x}$ & & \\
\hline & 3 & kapcsolattartó képesség & & $\mathrm{x}$ & & \\
\hline & 4 & kommunikációs készség & & $\mathrm{x}$ & & \\
\hline & 5 & szervezö készség & $\mathrm{x}$ & $\mathrm{x}$ & $\mathrm{x}$ & $\mathrm{x}$ \\
\hline & 6 & diplomáciai készség & & $\mathrm{x}$ & & \\
\hline & 7 & döntési képesség & & & $\mathrm{x}$ & \\
\hline & 8 & elemzö készség & $\mathrm{x}$ & & $\mathrm{x}$ & \\
\hline & 9 & eredményorientáltság & $\mathrm{x}$ & & & \\
\hline & 10 & $\begin{array}{l}\text { folyamatokban/rendszerekben } \\
\text { való gondolkodási képesség }\end{array}$ & $\mathrm{x}$ & & $\mathrm{x}$ & \\
\hline & 11 & kapcsolatteremtő képesség & & $\mathrm{x}$ & & \\
\hline & 12 & pontosság & & & & $\mathrm{x}$ \\
\hline & 13 & precizitás & $\mathrm{x}$ & & & \\
\hline & 14 & problémamegoldó képesség & $\mathrm{x}$ & & $\mathrm{x}$ & \\
\hline & 15 & stressztűrő képesség & $\mathrm{x}$ & $\mathrm{x}$ & $\mathrm{x}$ & \\
\hline & 16 & terhelhetőség & & $\mathrm{x}$ & & $\mathrm{x}$ \\
\hline & 17 & vezetői képesség & $\mathrm{x}$ & $\mathrm{x}$ & $\mathrm{x}$ & $\mathrm{x}$ \\
\hline \multirow{12}{*}{$\begin{array}{l}\text { Keller (1999) féle kom- } \\
\text { petenciák }\end{array}$} & 1 & kommunikáció & & $(\mathrm{x})$ & & \\
\hline & 2 & ellenőrzés & $\mathrm{x}$ & $\mathrm{x}$ & $\mathrm{x}$ & $\mathrm{x}$ \\
\hline & 3 & hatékony döntéshozás & & & $(\mathrm{x})$ & \\
\hline & 4 & motiváció & $\mathrm{x}$ & $\mathrm{x}$ & & \\
\hline & 5 & dolgozók fejlesztése & $\mathrm{x}$ & & $\mathrm{x}$ & \\
\hline & 6 & időgazdálkodás & & & & $(\mathrm{x})$ \\
\hline & 7 & prezentáció & & $\mathrm{x}$ & $\mathrm{x}$ & $\mathrm{x}$ \\
\hline & 8 & stressz-, konfliktuskezelés & $(\mathrm{x})$ & $(\mathrm{x})$ & $(\mathrm{x})$ & \\
\hline & 9 & szervezés & $(\mathrm{x})$ & $(\mathrm{x})$ & $(\mathrm{x})$ & $\mathrm{x}$ \\
\hline & 10 & kiválasztás, toborzás & $\mathrm{x}$ & $\mathrm{x}$ & $\mathrm{x}$ & $\mathrm{x}$ \\
\hline & 11 & betanítás, oktatás & & $\mathrm{x}$ & & \\
\hline & & Összesen & 12 & 15 & 11 & 8 \\
\hline
\end{tabular}

Összefoglalásként elmondható, hogy a Patóné féle kutatásban öt olyan kompetencia azonosítható, amely minden területen megjelent és további 12 kompetencia legalább három alrendszerben előfordul. Ezek összegzése az 1. mellékletben látható. Ehhez képest a CLM-kutatásban egyetlen olyan kompetencia van, amely minden területen megjelenik, a kommunikációs készség. Ugyanakkor számos kompetencia legalább két alrendszerben elöfordul, amint a 2. mellékletben összefoglaltuk.
Az 1. táblázatban a Patóné-féle kompetenciák rangsorában az első öt kompetenciát minden területen elvárják a munkáltatók (dőlt betűkkel), a vastagon szedett kompetenciák nemcsak az itthoni, hanem a Keller-féle kutatásban is megjelentek (ha nem is szó szerint, de tartalmában), amit ilyen formában kívántunk szemléltetni.

Az 1. táblázatban látható, hogy egy logisztikai kompetencia több általános kompetenciával is kapcsolatba hozható. Bár elképzelhető, hogy nem mindenki pontosan 
2. táblázat Kompetenciafejlesztő módszerek és kompetenciák (saját szerkesztés)

\begin{tabular}{|c|c|}
\hline Módszerek & Fejlesztett kompetenciák \\
\hline $\begin{array}{l}\text { 1/Tanulmányi kirándulás (Behrendt - Franklin, 2014): A tanár } \\
\text { és a tanulók hosszabb-rövidebb időre elhagyják az iskola falait a } \\
\text { való világgal való ismerkedés, új tapasztalatok megszerzése érdek- } \\
\text { ében. Célja, valóságos ismeretek nyújtása, olyan attitüdök kialakítá- } \\
\text { sa és olyan tapasztalatok szerzése, amelyek az iskola falai közt nem } \\
\text { elérhetők. }\end{array}$ & $\begin{array}{l}\text { tapasztalat, komplex szemléletmód, ismeretszer- } \\
\text { zés }\end{array}$ \\
\hline $\begin{array}{l}\text { 2/ Online tanulást segítőalkalmazások (kahoot, learning apps, } \\
\text { mentimeter): Játékos formában segíti az elméleti tudás elmélyítését } \\
\text { XXI. sz.-i eszközök segítségével. }\end{array}$ & $\begin{array}{l}\text { gyors döntéshozatal, komplex gondolkodásmód, } \\
\text { problémamegoldó készség, szabálykövetés }\end{array}$ \\
\hline $\begin{array}{l}\text { 3/ Szituációs játék (Kazainé, 2015): Az elsajátított ismeretek gya- } \\
\text { korlatba való átültetésére, felelevenítésére, vagy egy témakör lezárá- } \\
\text { sára, összefoglalására alkalmazott módszer. }\end{array}$ & $\begin{array}{l}\text { kommunikációs és tárgyalási készség, elemző és } \\
\text { problémamegoldó készség, komplex szemlélet- } \\
\text { mód, komplex gondolkodás, önismeret, szerepek, } \\
\text { szituációk értékelése, döntési képesség, érvelés }\end{array}$ \\
\hline $\begin{array}{l}\text { 4/ Rövid videók: Az elméletben megszerzett ismeretek könnyebb } \\
\text { megértését és elsajátítását segítő szemléltető módszer. }\end{array}$ & komplex szemléletmód, gyakorlati megközelítés \\
\hline $\begin{array}{l}\text { 5/ Csoportmunka: Kiindulása a tanulási cél. Egy feladat közös } \\
\text { megoldásával segíti egy témakör feldolgozását, a szintézisalkotást, } \\
\text { az általánosítások megfogalmazását, a problémamegoldás, illetve a } \\
\text { tudás bővítését és az együttmüködési készségek fejlesztését. }\end{array}$ & $\begin{array}{l}\text { társas együttmüködés, kreativitás, csoportos prob- } \\
\text { lémamegoldás, konstruktív tanulás }\end{array}$ \\
\hline $\begin{array}{l}\text { 6/ Projektmódszer (M. Nádasi, 2003): Valamilyen konkrét feladat } \\
\text { vagy probléma megoldása, nagyfokú szabadsággal a célok kiválasz- } \\
\text { tásától az eredmények értékeléséig. Projekteket általában a tanulók- } \\
\text { tanulócsoportok önállóan fogalmazzák meg egy adott élethelyzet, } \\
\text { megoldandó probléma alapján. }\end{array}$ & $\begin{array}{l}\text { problémamegoldó képesség. kreatív gondolkodás, } \\
\text { kooperációs készség, komplex információ kezelé- } \\
\text { se, tervezési és döntési képesség, önértékelés }\end{array}$ \\
\hline $\begin{array}{l}\text { 7/ Beszélgetés oktatási céllal: "Egy téma közös feltárása, a megér- } \\
\text { tési folyamatok elindítása a beszélgetés résztvevöiben. A módszer } \\
\text { lehetővé teszi, hogy a résztvevők kérdezzenek, felvessék saját prob- } \\
\text { lémáikat" (Dinnyés et al., 2001) }\end{array}$ & aktív tanulás \\
\hline $\begin{array}{l}\text { 8/ A tréningmódszer: Alapja az irányított gyakorlás, lehetőség sze- } \\
\text { rint a résztvevő készségszintü önálló tevékenységre való képességé- } \\
\text { nek eléréséig (Felnőttoktatási és képzési lexikon, 2002). }\end{array}$ & $\begin{array}{l}\text { az önismeretre alapuló önfejlesztés, kritika és ön- } \\
\text { kritika, mások befolyásolásának képessége } \\
\text { hatékony kommunikáció }\end{array}$ \\
\hline $\begin{array}{l}\text { 9/ A vita: A vita során vélemények, álláspontok ütköznek, ahol a } \\
\text { vitatkozó felek érvekkel vagy érzelmekkel győzik meg egymást saját } \\
\text { igazukról. }\end{array}$ & $\begin{array}{l}\text { aktivitás, logikus, komplex gondolkodás, helyes } \\
\text { érvelés, tolerancia, kritikai attitüd, } \\
\text { énkép, önismeret }\end{array}$ \\
\hline $\begin{array}{l}\text { 10/ A moderációs módszer: A résztvevők önálló tanulási folya- } \\
\text { maton keresztül szerzik meg az ismereteket és oldják meg az adott } \\
\text { problémát. A sikeres kivitelezéshez fontos a jól felkészült moderátor } \\
\text { - nem szaktekintélye az adott témának -, aki támogató funkciót tölt } \\
\text { be az ötletek felszínre hozásával, jó kérdések megfogalmazásával. }\end{array}$ & $\begin{array}{l}\text { kooperációs készség, kreativitás, értékelés } \\
\text { rendszerszemlélet, gondolatok verbális és vizuális } \\
\text { megjelenítése }\end{array}$ \\
\hline $\begin{array}{l}\text { 11/ Esettanulmány módszere: A valóságból származó - közlemény, } \\
\text { szakirodalom, saját tapasztalat alapján - írásban bemutatott szituá- } \\
\text { ció feldolgozása előzetes ismeretek, tapasztalatok segítségével. }\end{array}$ & aktív gondolkodás, kreativitás \\
\hline $\begin{array}{l}\text { 12/ Vendégelőadó (Horváth, 2015): Részt vesz (vehet) az egyetemi } \\
\text { tananyagok írásában és lektorálásában. Szakdolgozathoz kapcsolódó } \\
\text { témavezetői és bírálati feladatokat vállal(hat). }\end{array}$ & $\begin{array}{l}\text { látókör, gyakorlati tapasztalat bővülés, kapcsolat- } \\
\text { teremtő képesség, kommunikációs képesség }\end{array}$ \\
\hline 13/ Prezentációtartás egyénileg, előzetes felkészülés alapján & $\begin{array}{l}\text { prezentációs készség, önálló gondolkodás, időgaz- } \\
\text { dálkodás, látókör }\end{array}$ \\
\hline 14/ Prezentációtartás csoportosan, előzetes felkészülés alapján & $\begin{array}{l}\text { társas együttmüködés, kreativitás, csoportos prob- } \\
\text { lémamegoldás, konstruktív tanulás, prezentációs } \\
\text { készség, időgazdálkod ás, empátia, látókör }\end{array}$ \\
\hline 15/ Csoportos házi feladat készítés & $\begin{array}{l}\text { társas együttmüködés, kreativitás, csoportos prob- } \\
\text { lémamegoldás, konstruktív tanulás, időgazdálko- } \\
\text { dás, empátia, látókör }\end{array}$ \\
\hline
\end{tabular}


így párosította volna a kompetenciákat, a jelen párosítás alapján a szociális kompetencia tünik a legfontosabbnak és az időgazdálkodás a legkevésbé fontos kompetenciacsoportnak.

Az elvárt kompetenciákat megvizsgálva két fontos megállapítás tehető: 1) a logisztika területén korábbi kutatások alapján feltárt kompetenciák többnyire bármely más szakterületen is elvárhatóak, általánosnak tekinthetőek; ez a megállapítás azért is fontos, mert eredményeink éppen ezért nemcsak a logisztikai képzésekre, de máshol is használhatóak, 2) a feltárt kompetenciák legnagyobb része tanulható és fejleszthető, ami a cikk középpontjában álló oktatás szempontjából fontos.

A következő fejezetben át is térünk az oktatási szempontú megközelítésre és összeszedjük, milyen lehetőségek állnak a kooperatív oktatás-módszertani megközelítések tárházából rendelkezésre a kompetenciák fejlesztésére.

\section{Kompetenciákat fejlesztő módszerek}

A fentebb bemutatott kutatások alapján megállapítható, hogy a logisztika területén dolgozó munkaerővel szemben olyan kompetenciák fogalmazódnak meg elvárásként, melyek fejlesztése kooperatív módszerek alkalmazásával sokkal hatékonyabb, mint a legtöbb ember számára ismert és leginkább alkalmazott hagyományos oktatási módszerekkel.

A kooperatív (együttmüködő) “csak” az egyik módszer az individuális (egyéni/önálló) és a kompetitív (versenyeztető) tanulásszervezés mellett. Az utóbbi módszerek közül a mindenki számára ismert és hagyományosnak mondható kompetitív módszer lényege, hogy az óra frontális módszerekre épül, a tanár van központi szerepben, akinek a figyelméért és dicséretéért ,versengenek" a tanulók. Az individuális tanulás a dif- állnak. A következőkben egy áttekintő táblázat (2. táblázat) segítségével bemutatjuk néhány ismert kooperatív módszer fö jellemzőit és az általuk fejleszthető kompetenciákat (Cserné, 2006).

A 3. táblázatból jól látható, hogy egy-egy kompetencia fejlesztésére többféle módszer is használható. A módszerek kiválasztásakor és alkalmazásakor a tanár dönti el, hogy számára mely módszer lenne kézenfekvő, amit kombinálhat is az eredményesség érdekében.

A fejlesztéshez számtalan segédletet, javaslatot, technikát dolgozott már ki többek között Spencer és Miguel Kagan (2010), hogy segítsék az oktatók munkáját a célok elérése érdekében. A kooperatív tanulás módszertana Magyarországon is fontos, elismert, adaptált és valamennyi iskolában - a pedagógus igénye és felkészültsége szerint - használható rendszer az oktatás során. Alkalmazásához nincs szükség nagy beruházásokra, struktúrák átszervezésére, speciális rendszerek létrehozására. Bevezetéséhez elegendő akár egyetlen lelkes, elszánt tanító, tanár is, akinek célja, hogy a diákok jobb hangulatú órákon, stresszmentesen, minél hasznosabban és több tudást elsajátítva készüljenek a való életre, elhagyva a ma jellemző versenyeztető és frontális módszer hátrányait.

A kooperatív tanulás módszere magában foglalja a kooperáció megvalósítását. Ha nem tud együttműködni a csoport az adott cél érdekében, akkor a feladat megoldhatatlanná válik számára. Ennek fontossága munkavállalás során még inkább előtérbe kerül, hiszen ma már kevés olyan munkakör létezik, ahol nem kell másokkal együttmüködve a vállalati célok megvalósításán dolgozni.

A kooperatív módszerek alkalmazása tehát kiemelt fontosságú, de nemcsak a munkáltatók miatt, hanem

3. táblázat A beszerzési kompetenciák fejlesztésének oktatási módszerei (saját szerkesztés)

\begin{tabular}{|l|l|}
\hline \multicolumn{1}{|c|}{$\begin{array}{c}\text { Beszerzés területén elvárt } \\
\text { kompetenciák }\end{array}$} & \multicolumn{1}{c|}{ Módszerek } \\
\hline ellenőrzés & vita, moderációs módszer, szituációs játék \\
\hline felelősségtudat & projektmódszer, tréningmódszer, vita, moderációs módszer \\
\hline kifejező készség & $\begin{array}{l}\text { szituációs játék, tréningmódszer, moderációs módszer, prezentációtartás, } \\
\text { vendégelőadó }\end{array}$ \\
\hline kockázatvállalási készség & esettanulmány módszere, tréningmódszer \\
\hline komplex gondolkodásmód & online alkalmazások, szituációs játék, rövid videók, projektmódszer \\
\hline tárgyaló képesség & szituációs játék, tréningmódszer, vendégelöadó \\
\hline vállalati szinten való gondolkodásmód & szituációs játék, rövid videók, projektmódszer \\
\hline vevőorientáltság & prezentációtartás csoportosan, csoportos házi feladat készítés \\
\hline
\end{tabular}

ferenciált oktatás egyik legismertebb formája, ahol a tanulók önállóan dolgozzák fel a részükre kiosztott feladatot és a tanártól „,személyre szabott” segítséget kaphatnak, amennyiben szükségük van rá. Mivel az anyagot számukra legmegfelelőbb tempóban sajátítják el, így a megszerzett tudás biztosnak mondható. Természetesen mindegyik módszernek megvannak a maga elönyei és hátrányai, melyeket ismerve az adott cél elérése érdekében használja és kombinálja őket az oktató.

A jelen cikk középpontjában a kooperatív módszerek mert az "x", "y", és leginkább a "z" generáció oktatással szemben támasztott igényeit a frontális módszer ma már nem elégíti ki (Tari, 2010, 2011). Célokat, eredményeket leginkább a rendelkezésre álló eszközök (iskolai és tanulói egyaránt) és módszerek kombinálásával lehet elérni.

Tehát a logisztikai képzésekben az oktatás módszertana úgy alakítható, hogy a potenciális munkáltatók, illetve munkavállalók is elégedettek legyenek. Már „,csak” 
a kívánt kompetenciák fejlesztésének lehetséges módjait, kereteit és a képzési kimeneti kritériumokhoz való illesztését kell kidolgozni.

\section{Az oktatás különböző szintjei}

A logisztikai oktatásnak Magyarországon több szintje is létezik. A legalacsonyabb szintet az OKJ-képzések adják. A szakmai és vizsgakövetelmény szerint az OKJ-s - 5484111 Logisztikai és szállítmányozási ügyintéző képzés során a hallgató a következő feladatok megoldását sajátítja el: logisztikai tevékenységek tervezése, lebonyolítása, a logisztikai rendszerrel kapcsolatos vezetői munka támogatása, valamint a szállítmányozási tevékenységgel kapcsolatban az áru továbbításához legalkalmasabb fuvarozási mód kiválasztása, szükség szerint az útvonal megtervezése. Kapcsolatot tart a különböző közlekedési hatóságokkal, szervezetekkel. Elkészíti a szállítmányozási szerződés tervezetét. Kockázatot csökkent a kereskedelmi ügyletnek megfelelő szállítmánybiztosítási ajánlattal. Gondoskodik a különböző fuvarozók információkkal való ellátásáról. Részt vesz a különböző fuvareszköz-, illetve árukárok kivizsgálásában, intézi a kárügyeket, ellenőrzi és kiadja a különböző fuvarokmányokat stb.

Bár specializációként néhány egyetemen, például a BGE-n megjelenik alapszinten a logisztika, önálló szakként (2018 óta ellátásilánc-menedzsment néven), csak mesterszinten elérhető. A felvi.hu tájékoztatása szerint „A képzés célja ellátásilánc-menedzserek képzése, akik az integrált vállalati logisztikai menedzsment összefüggéseit átlátva képesek a vállalati logisztikai rendszer és a vállalatokat átfogó ellátási láncok irányítására. A szükséges elméleti tudás birtokában, illetve a modern gyakorlati megoldások ismeretében képesek a vállalaton belüli, illetve a vállalatok közötti logisztikai folyamatok terve- zésére, elemzésére és fejlesztésére, illetve azok hatékony vezetésére. Felkészültek tanulmányaik doktori képzésben történő folytatására."

Látható, hogy míg az OKJ-s bizonyítvány föleg ügyintézői képességekkel vértezi fel a leendő munkavállalót, addig a mesterszintü diploma gazdasági szaktudással, komplex folyamatokat átlátó és döntéseket hozni képes szakembert ígér. Ezek az eltérő szintek Patóné (2006) elemzéséből nem derülnek ki, de Keller (1999) felmérésében megjelennek, amikor egy-egy szakterületen belül a vezetőkre az adott terület alapkompetenciáin kívül továbbiakat is megfogalmaz (ld. 2. ábra).

\section{A kutatás célja és terepe}

Az eltérő célok alapján tehát azt valószínüsíthetjük, hogy a képzési célokat más oktatási módszerek képesek biztosítani. Mivel a kooperatív módszerek közül több is a döntéshozatal, a rendszerszintü gondolkodás, a tervezési és irányítási képességek fejlesztését célozza, ezért valószínüsíthető, hogy azok a mesterszintü képzések céljával inkább összhangban vannak, mint az OKJ-szinttel. Ezért két hipotézist fogalmazunk meg:

H1: A mesterszakos hallgatók a kooperatív oktatási módszereket jobban ismerik, mint az OKJ-sek.

H2: A mesterszakos hallgatók a kooperatív oktatási módszereket hasznosabbnak tartják, mint az OKJ-sek.

Ilyen jellegü kutatásról - ahol oktatási módszerek használatát két eltérő szinten vizsgálják, és tanulói szemszögből - nem lelhető fel szakirodalom. Az a tény, hogy a korábban bemutatott, munkaerő-piaci elvárásokat összefoglaló tanulmányok 1999-ben és 2006-ban születtek, a vizsgálat egyedi jellegétől függetlenül is megköveteli az adatok aktualizálását.

Hazánkban a logisztikai jellegü tanulmányok iránt érdeklődőknek számos és egyre bővülő lehetősége nyílik

4. táblázat A hallgatók kooperatív módszerekkel kapcsolatos ismeretei (saját kut.)

\begin{tabular}{|l|l|c|c|c|c|c|}
\hline Ssz. & Módszerek & $\begin{array}{c}\text { OKJ } \\
\mathbf{\%}\end{array}$ & $\begin{array}{c}\text { Mester } \\
\mathbf{\%}\end{array}$ & $\begin{array}{c}\text { Össz } \\
\mathbf{\%}\end{array}$ & $\begin{array}{c}\text { Jelölések } \\
\text { száma }\end{array}$ & Szignifikancia \\
\hline 1 & Csoportmunka & 90,3 & 96,4 & 94,2 & 81 & $\mathrm{p}(\mathrm{v})=0,254$ \\
\hline 2 & Tanulmányi kirándulás* & 71,0 & 96,4 & 87,2 & 75 & $\mathrm{p}(\mathrm{v})=0,001$ \\
\hline 3 & $\begin{array}{l}\text { Online - tanulást segítő - alkalmazások } \\
\text { kahoot, learning apps, mentimeter...* }\end{array}$ & 58,1 & 82,1 & 74,4 & 64 & $\mathrm{p}(\chi)=0,015$ \\
\hline 4 & Esettanulmány módszere* & 38,7 & 91,1 & 72,1 & 62 & $\mathrm{p}(\chi)=0,000$ \\
\hline 5 & Vendégelőadó* & 45,2 & 85,7 & 72,1 & 62 & $\mathrm{p}(\chi)=0,000$ \\
\hline 6 & Szituációs játékok* & 38,7 & 85,7 & 69,8 & 60 & $\mathrm{p}(\chi)=0,000$ \\
\hline 7 & Rövid videók & 61,3 & 75,0 & 69,8 & 60 & $\mathrm{p}(\chi)=0,181$ \\
\hline 8 & Projektmódszer & 58,1 & 60,7 & 59,3 & 51 & $\mathrm{p}(\chi)=0,809$ \\
\hline 9 & Beszélgetés oktatási céllal & 54,8 & 46,4 & 50,0 & 43 & $\mathrm{p}(\chi)=0,452$ \\
\hline 10 & A vita & 38,7 & 55,4 & 48,8 & 42 & $\mathrm{p}(\chi)=0,137$ \\
\hline 11 & A tréningmódszer & 29,0 & 37,5 & 34,9 & 30 & $\mathrm{p}(\chi)=0,426$ \\
\hline 12 & A moderációs módszer & 9,7 & 14,3 & 12,8 & 11 & $\mathrm{p}(\mathrm{v})=0,528$ \\
\hline
\end{tabular}

$(p(v)$ :valószínűségi hányados; $p(\gamma)$ :khí négyzet; *:p<0,05) 
mind közép-, mind felsőszinten, hiszen napjainkban szinte minden jelentősebb müszaki, gazdasági felsőoktatási intézményben megtalálható ilyen ,,jellegü” képzés.

A kutatásban részt vett felsőfokú tanulmányokat folytató hallgatók a Budapesti Corvinus Egyetem Ellátásilánc-menedzsment mesterszakára járnak, három különböző csoportba. Ök jellemzően az alapszak elvégzése után jelentkeztek mesterszintű logisztikai képzésre. Választásukat az is befolyásolta, hogy az egyetem alapszakos hallgatóiként döntő többségük már az első évükben megismerkedhetett a logisztikai szemlélet alapjaival a Vállalatgazdaságtan címü tantárgy keretein belül. Ezt követöen a harmadik évfolyamon - mintegy alapozó tárgyként - sokuknak megjelenik a Tevékenységmenedzsment címü tantárgy, ami bevezető kurzusként folyamatszemléletben tárgyalja a logisztika és a termelésmenedzsment alapvető tevékenységeit, illetve a strukturált problémamegoldás módszereit.

A középfokú képzésben $(\mathrm{OKJ})$ részt vevő tanulók két budapesti szakgimnázium érettségi utáni logisztikai ügyintéző (egy csoport), illetve logisztikai és szállítmányozási ügyintéző (négy csoport) képzések nappali és esti tagozatos hallgatói voltak. Mivel az érettségin kívül más egyéb bemeneti kritérium nincs, ezért más középfokú oktatási intézményekben, vagy oktatásszervező cégek szervezésében is van lehetőség logisztikai témájú szakok elvégzésére $(\mathrm{OKJ})$.

\section{Kutatásmódszertan}

A megkérdezés egy online kérdőív segítségével történt 2017 októberében. A válaszok összegyüjtésének módja minden csoportban megegyezett. Egy, az adott csoport minden tagja által látható felületen - Moodle, Facebook jelent meg a kérdöív linkje - egy rövid üzenettel a kutatás céljáról-, amelyre kattintva (akár telefon, akár számítógép használatával) kitölthető volt a 14 zárt kérdéscsoportból álló, többnyire Likert-skálán jelölhető válaszokat tartalmazó online kérdöív. A részvétel önkéntes volt, a kérdőív kitöltésében 86 hallgató közremüködött és a válaszadási hajlandóság 53,8\% volt.

\section{Eredmények}

A válaszadó hallgatók képzési szintek szerinti megoszlása: OKJ: 35\%, mesterszint:65\%. A kitöltök nemek szerinti eloszlása: $72 \%$ nő és $28 \%$ férfi. A válaszadók $90 \%$-a 18-26 év közötti és csupán 10\%-a 30 év feletti.

\section{Az egyes módszerek ismerete a felmérés szerint}

Az egyes módszerekről alkotott hallgatói vélemény felmérése előtt fontos volt azok ismertségéről tájékozódni. A kérdőívben szereplő kérdés a következő volt: „Mely kooperatív oktatási módszer ismert az Ön számára? Több válasz is jelölhetö!” A válaszlehetőségeket a már korábban bemutatott kooperatív módszerek adták (4. táblázat).

Mivel az OKJ és a mester összehasonlítása során több olyan cella is volt, ahol a mintaelemszám nem érte el az ötöt (például csak ketten nem ismerték a tanulmányi kirándulást), ezért a khí-négyzet próba helyett az ilyen esetekre ajánlott valószínűségi hányadost használtuk (Falus et al., 2008). Az eredmények alapján a tanulmányi kirándulás, az online alkalmazások, az esettanulmány, a vendégelőadó és a szituációs játékok - statisztikailag szignifikáns módon alátámasztva is - ismertebbek a mesterhallgatók

5. táblázat Az egyes oktatási módszerek megítélése a fejlesztési képességeik szerint (saját kutatás)

\begin{tabular}{|l|c|c|c|c|}
\hline Az egyes módszerek hasznosságának megítélése átlagosan & OKJ & Mester & Átlag & $\begin{array}{c}\text { Mann- } \\
\text { Whitney U } \\
\text { próba }\end{array}$ \\
\hline Csoportmunka* & & & & \\
\hline Projektmódszer & 4,37 & 3,89 & $\mathbf{4 , 0 6}$ & 0,035 \\
\hline Prezentációtartás egyénileg, elözetes felkészülés alapján & 4,10 & 3,95 & $\mathbf{4 , 0 1}$ & 0,619 \\
\hline Szituációs játék & 4,07 & 3,89 & $\mathbf{3 , 9 5}$ & 0,308 \\
\hline Tanulmányi kirándulás & 4,00 & 3,84 & $\mathbf{3 , 8 9}$ & 0,630 \\
\hline A vita & 3,96 & 3,80 & $\mathbf{3 , 8 5}$ & 0,472 \\
\hline Beszélgetés oktatási céllal*** & 4,08 & 3,67 & $\mathbf{3 , 8 2}$ & 0,106 \\
\hline Prezentációtartás csoportosan, előzetes felkészülés alapján & 4,20 & 3,46 & $\mathbf{3 , 7 8}$ & 0,006 \\
\hline Esettanulmány módszere & 3,90 & 3,61 & $\mathbf{3 , 7 1}$ & 0,202 \\
\hline Vendégelőadó** & 3,87 & 3,64 & $\mathbf{3 , 7 1}$ & 0,423 \\
\hline Csoportos házi feladat készítés & 4,00 & 3,47 & $\mathbf{3 , 6 5}$ & 0,019 \\
\hline Rövid videók*** & 3,48 & 3,41 & $\mathbf{3 , 4 4}$ & 0,656 \\
\hline $\begin{array}{l}\text { On-line - tanulást segítő - alkalmazások (kahoot, learning apps, } \\
\text { mentimeter..)*** }\end{array}$ & 3,86 & 3,15 & $\mathbf{3 , 4 0}$ & 0,001 \\
\hline A moderációs módszer & 3,31 & 3,19 & $\mathbf{3 , 2 5}$ & 0,793 \\
\hline
\end{tabular}


körében, az összes többi módszerben azonban nincs szignifikáns különbség.

A két célcsoportot együtt vizsgálva elmondható, hogy a legismertebb módszerek közé tartozik a csoportmunka és a tanulmányi kirándulás. A legkevésbé ismert módszerek a tréning és a moderációs módszer.

\section{Az egyes módszerek fejlesztési képességei a felmérés szerint}

Miután a résztvevők az egyes oktatási módszerek ismertségét végiggondolták, végig kellett gondolniuk, hogy véleményük szerint mennyire segítik ezek a módszerek az ellátási lánc egyes területein elvárt kompetenciák fejlesztését. Az „elvárt kompetenciák” köre ismert volt a hallgatók előtt a kérdőívben szereplő korábbi kérdések alapján úgy, mint tárgyaló készség, együttműködési készség, rendszerszemlélet, csapatban történő munkavégzés, kommunikációs készség, kapcsolatteremtő képesség, prezentációs készség, szervezőkészség, irányítási készség, önálló döntéshozás képessége, üzleti szemlélet, ügyfélközpontúság, konfliktuskezelés, stressztürő képesség, szabálykövetés képessége, ellenőrzés és értékelés képessége, következetesség. A kérdőívben szereplő kérdés a következő volt: "Véleménye szerint a felsorolt oktatási módszerek milyen mértékben segítenek az ellátási lánc egyes területein (beszerzés, termelés, raktározás, disztribúció) elvárt kompetenciák fejlesztésében? (1: egyáltalán nem 5: teljes mértékben)".

Az OKJ és a mester összevetésekor statisztikai próbaként a két minta átlagának összevetésére szolgáló MannWhitney U tesztet használtuk (Falus et al., 2008). A statisztikai próba alapján a csoportmunka, a beszélgetés, a vendégelőadó, a rövid videók és az online alkalmazások terén találunk különbséget. Meglehetősen furcsa, hogy mindegyik különbség esetén az OKJ-hallgatók tartották jobbnak az adott eszközt.

A módszerek közül a csoportmunka, a projektmunka és az egyéni prezentációk bizonyultak a leghatékonyabb módszereknek. Meglepő eredmény, hogy az órákon előszeretettel és lelkesedéssel használt online alkalmazások (pl.: kahoot) viszonylag rosszul szerepeltek, különösen a mesterszakon. De a csoportos házi feladatok és a rövid videók sem kaptak túl pozitív értékelést (5. táblázat).

\section{Eredmények értékelése}

A középfokú és felsőfokú képzésben résztvevők között az egyes módszerek ismertségében legnagyobb különbség az esettanulmányos módszer, a vendégelőadás és a szituációs játékban van. Az előbbi és az utóbbi egyértelműen magyarázható a képzés eltérő szintjével, hiszen ezek a módszerek a döntési helyzetek, a komplex problémák megoldásában segítik a diákokat. A vendégelőadás terén tapasztalható különbség is abból fakadhat, hogy az egyetemi hallgatóknak már életszerü és vezetői problémákat mutatnak be. Az online módszerek eltérő ismertsége inkább az oktatástechnika és az oktatói felkészültség különbségéböl fakadhat.

Ezek az eredmények megerősítik a két különböző oktatási szint által megfogalmazott különbségeket, az OKJ- képzésre járó tanulók valószínüleg azért ismerik kevésbé az egyes módszereket, mert azokat náluk az oktatásban nem használják.

Elnevezéséből adódóan a moderációs módszer sokaknak ismeretlennek tűnhetett, valószínűleg nem rendelkezik a módszer olyan speciális karakterjegyekkel, amelyeket a tanulók felismerhetnek. Lehet, hogy érdemes lenne ezt a módszert egy kicsit explicitebb módon megjeleníteni, felismerhetővé tenni. Mindenesetre ezzel a témával érdemes volna tovább foglalkozni.

Az egyes módszerek ismertségére felállított H1 hipotézist az eredmények tükrében elfogadjuk. Bár olyan eszközöket nem azonosítottunk, amelyeket az OKJ-tanulók szinten jobban ismernének, mint a mesterszakos hallgatók, de több olyat is találtunk, amelyeket az utóbbi csoport ismertebbnek tartott. Ez összhangban van Keller (1999) kutatásával, amelyben például a raktárvezető (ld. 2. ábra) a raktári dolgozók képességhalmazán túl rendelkezik további képességekkel.

Áttérve a H2 hipotézisre, az ott kapott eredmények sokkal nehezebben értelmezhetőek. Az látható, hogy az OKJ-hallgatók - bár nem mindenhol szignifikánsan -, de hatékonyabbnak tartották az összes felsorolt módszert, mint a mesterszakosak, még azokat is, amelyeket nem ismernek. Magyarázhatjuk ezt az eredményt azzal, hogy az alacsonyabb képességekkel rendelkezők kevésbé kritikusak. De ad abszurdum az is elképzelhetö, hogy a mesterszintü oktatás hatékonyságát az oktatói felkészültség hiánya magyarázza. Hiszen míg a középfokú képzésben oktatóknak kell rendelkezniük pedagógusi végzettséggel, addig a felsőfokú képzésben oktatóknak csak témájukban kell magas szintű képzettséggel rendelkezniük, ez felvételük kritériuma. Bár vannak olyan felsőfokú intézmények - föként külföldön -, ahol az oktatók oktatás-módszertani képzésének is figyelmet szentelnek - például egy kötelező képzésen át kell menniük, mielőtt oktathatnak - ez a magyar felsőfokú képzésben egyáltalán nem jellemző. Nem jellemző a BCE-re sem, ahova a mintában szereplő mesterszakos tanulók járnak. Bár vannak erőfeszítések arra, hogy a Pedagógiai Intézet önkéntes formában segítséget nyújtson az oktatóknak, idő hiányában ezt viszonylag kevesen veszik igénybe. Az eredmények alapján mindenesetre a H2 hipotézist el kell utasítanunk, nemhogy hasznosabbnak, de néhány módszer esetében kifejezetten kevésbé hasznosnak tartják a hallgatók az értékelt oktatási módszereket.

A legmeglepőbb eredményt az online módszerek produkálták. Mivel ez az oktatási módszer a jövőben egészen biztosan egyre nagyobb fajsúlyt fog képviselni, ezért úgy döntöttünk, hogy néhány tanulótól részletes, írásos véleményt is kérünk a rossz eredmények okairól. Ezek a vélemények olvashatóak a 6 . táblázatban.

A tanulói vélemények alapján az online oktatási módszerek használatának módja és a rendelkezésre álló technológia azok a tényezők, amelyek elsősorban befolyásolják a módszerről kialakított általános képet.

\section{Következtetések}

A cikkben a logisztika oktatásban fejlesztett és a gyakorlatban elvárt kompetenciák kapcsolatát tártuk fel, 
melyhez új megközelítésként a hallgatók véleményét használtuk fel úgy, hogy a logisztika területein közép- és felsőfokú oktatásban (OKJ és MSc) részt vevő hallgatókat kérdeztük meg a bemutatott kooperatív módszerek ismertségéről és hatékonyságukról.

A téma fontosságát a gazdaságban és ezen belül a logisztikai szektorban végbemenő változások, a felsőokta- tásba bekerülő hallgatók jellemzőinek változásai (Takács et al., 2017), valamint a munkáltatók és a hallgatók - potenciális munkavállalók - elvárt kompetenciákkal kapcsolatos elgondolásának megismerése indokolja.

Munkánk hozzáadott értéke, hogy két különböző szinten - OKJ és mester - logisztikát tanulók véleményét méri fel az oktatás során alkalmazott kooperatív oktatá-

6. táblázat Hallgatói vélemények az online módszerekről

\begin{tabular}{l}
\hline Mesterszak \\
\hline Az online módszereknek szerintem csak a számonkérés része hasz- \\
nosítható, tudásátadásra kevésbé használható. Az e-learninges tesz- \\
teknél sok esetben a könyv is használható, ami alapvetően nem baj, de \\
legtöbbször el sem olvassuk az anyagot, ha digitális formában elérhető \\
a könyv, akkor „ctrl+F” funkció segítségével rákeresünk a kulcssza- \\
vakra, elolvassuk a szövegkörnyezetet és megadjuk a helyes választ. \\
Így kimarad az ismétlés, szerintem nem elég, ha csak egyszer találko- \\
zunk az információval. \\
\hline A Kahoot-ról is hasonló a véleményem, hogy ismétlésre, számonké- \\
résre vicces, hasznos, élvezetes, de ismeretátadásra nem alkalmas. \\
Nincs elegendő idő feldolgozni a kérdést, valamint a válaszokat sem, \\
mert az idővel is versenyezni kell. 4-5 perc alatt legalább 10 téma- \\
körrel foglalkozunk, nincs ideje ülepedni a hallott/olvasott informá- \\
cióknak.
\end{tabular}

Tény, hogy sokszor elöfordul, hogy valami nem müködik és ez nem igazán jut a tanár tudomására. Én például egyszer lefrissítettem a kahoot oldalamat és hát ugye utána nem lehet visszalépni csak másik felhasználóval. Volt olyan is, hogy lefagyott a telefon, meg olyan is, hogy az egyik csoporttárs elkezdett panaszkodni, így az egész csoport lemaradt egy feladatról.

Az alacsony átlag szerinti pontszáma véleményem szerint (más online tanulás segítő alkalmazással nem igen találkoztam visszatérően tanulmányaim során, így a kategória alacsony pontszámát csak a Kahoot kapcsán tudom értékelni, megítélni) abból eredhet, hogy a játék általában kötelező az órákon és kimondottan aktivitást igényel, elképzelhetönek tartom, hogy ezt nem minden hallgató preferálja. Továbbá helyezést ér el minden hallgató, amely a helyes/helytelen válaszok mellett a válaszadás gyorsaságán is múlik. Megeshet, hogy valaki tudná a helyes választ, ha több ideje lenne a kérdés végiggondolására és nem kellene a gyorsasággal is foglalkoznia.

A Kahoot példáján végiggondolva, számos esetben váratlanul éri a hallgatókat a „felkérés”. Ha lehet rá számítani, és előre tudott a témakör, akkor a röpdolgozatnak kiváló alternatívája lehetne ez a módszer, feltéve, ha hagynak időt a válaszok megadására. Figyelembe kell venni ennél a lehetőségnél ugyanis, hogy a hallgatók különböző technikai felszereltséggel rendelkeznek (gyorsabb/lassabb okos telefon, tablet, laptop, wifi kapcsolat/mobil internet), így egyes termekben, ahol gyenge az egyetemi wifi jel, ott hátrányból indul az, akinek nincsen jó lefedettséggel rendelkező mobil szolgáltatója, valamint elegendő adatmennyisége.
A hallgatók informatikai érdeklődése, tudása is számít. Nem mindenki barátja a mai gépesített világnak. Nagyban függ ez a pontszám attól, hogy a hallgatók életkora hogyan alakul, számít, hogy hol élnek (város, falu). Ezt a területet lehet erősíteni, a cégemnél több képzést is már e-learning alapon kapunk pps, videó, szöveges információk útján, a végén meg teszt van, amit többször meg lehet ismételni. De nálunk sem mindegy, hogy ki hány éves, milyen gyors a számítógépen... stb. Szerintem még egy generáció kell az online oktatás, e-learning széles körü elterjedéséhez.

Nagyon szerettem kahootolni. Igazából fárasztó volt az is, mert elég gyorsan kellett gondolkodni és a zene is stresszelt mellette. Azt utáltam. Szerintem ezeket a játékokat mindenki szereti, ezért kaphatott jó eredményt.

Hasznos, szórakoztató és elősegíti a gyors és rövid tanulást és a versenyszellemet is táplálja, föleg, ha vannak apróbb jutalmak. 
si módszerek ismertségéről és hasznosságáról. Eddig a szükséges kompetenciákat csak a munkáltató oldaláról vizsgálták, és a két oktatási szintet nem különböztették meg egymástól.

Az irodalomkutatásban feltárt szükséges kompetenciákat vizsgálva arra jutottunk, hogy nagy részük az oktatás során fejleszthetö, ezért nagyon fontos, hogy mind az elvárt kompetenciák, mind a fejlesztésüket szolgáló módszerek ismertek legyenek az oktatók számára. A tanulmányban ezért röviden bemutatunk olyan kooperatív oktatási módszereket, melyek a kívánt kompetenciák elsajátítását szolgálják. A módszerek és a kompetenciák összepárosítása során megállapítást nyert, hogy sikeres „együttmüködés” valósítható meg a konkrét cél (fejlesztendő kompetencia) és elérési módjának (kooperatív módszer) alapos megtervezésével. Az elvárt kompetenciákon túl számos fejleszthető kompetencia szerepel még a módszertani táblázatban, ami rugalmasságot és az esetlegesen felmerülő új igényeknek való megfelelést tesz lehetővé az oktatók számára. Hangsúlyozzuk, hogy a bemutatott kooperatív oktatási módszerek nemcsak a logisztikai képzésben használhatóak, hiszen a logisztikai kompetenciák nagy része általános kompetenciának mondható.

A hipotézisvizsgálat alapján beigazolódott, hogy a mesterszakos hallgatók többféle kooperatív módszert ismernek (H1), ami felébresztheti a reményt, hogy ez a széles módszertani portfólió felruházza a tanulókat a piacon elvárt képességekkel. A hipotézisvizsgálatból az is látszik, hogy számos módszer van, ami OKJ és mesterszinten egyaránt használatos. Ez az eredmény azt is mutatja, hogy a kooperatív módszerek és a velük fejlesztett kompetenciák ma már nemcsak az egyetemi képzésben, hanem alacsonyabb szinten is elvártak.

A H2 hipotézis vizsgálata rávilágított arra, hogy a széles módszertani repertoár hatékonysága a mesterszakos hallgatóknál még csiszolásra szorul. Mivel a viszonylag rossz értékelés okait csak találgatni tudtuk, ezért néhány hallgatót megkértünk az eredmények értelmezésére (verifikálás). Véleményük megerősítette azt a feltételezést, hogy nem feltétlenül a módszertannal, sokkal inkább annak alkalmazási módjával és lehetőségeivel van probléma.

Cikkünknek mindenképpen egyik alapvető javaslata, hogy a közép- és felsőfokú intézményekben nagyobb figyelmet kell szentelni az oktatás-módszertani kérdéseknek. Főként azért, mert a mai tanulók már egészen mást - leginkább azonnal használható tudást - várnak el, és mindezt szórakoztató, figyelmet lekötő módon. Itt már nem elég az oktató szakmai tudása (az viszonylag kis arányban segíti a sikeres üzleti tevékenységet, ld. Derwik et al., 2016, 2017), egyre fontosabbá válik az, hogy közben a tanulók szoft képességeinek fejlesztésére is figyeljen.

Kutatásunknak két fontos korlátja van. Az egyik ilyen korlát, hogy az alapszintü logisztikai képzéssel nem foglalkoztunk. Ennek a szintnek a bevonása egyben segítene abban is, hogy az alap- és mesterszintü képzés közötti különbségeket - vagy esetleg azok hiányát - meg tudjuk ragadni. Ezáltal jobban lehetne arra a kérdésre is választ adni, hogy vajon miért éri meg egy diáknak, hogy az alapszint elvégzése után további két évet az iskolapadban tölt- sön. És persze ez a vállalati oldalon is világosabbá tenné, miért éri meg a fiatal munkatársakat a mesterszintre is elengedni, vagy beiskolázni, esetleg az onnan érkezőket jobban megfizetni.

További korlát és egyben kutatási lehetőség a munkáltatók által elvárt kompetenciák adatbázisának frissítése, figyelembe véve az egyes oktatási szinteket itthon és nemzetközi szinten, illetve a betöltött munkakörök szintjeit McKinnon (2017). Ez nagyon aktuális lenne, hiszen a 2006-os, illetve 1999-es felmérések óta sok idő telt el, óriási technológiai és társadalmi változásokkal füszerezve. A folyamatos gazdasági változások hatására felmerül, hogy az általunk ismert kompetenciák már nem teljesen illeszkednek az adott feladathoz.

\section{Felhasznált irodalom}

Ballér E., Golnhofer E., Falus I., Kotschy B., M. Nádasi M., Nahalka I., ...Vámos Á. (2003): Didaktika. Budapest, Magyarország: Nemzeti Tankönyvkiadó Rt. https://www.tankonyvtar.hu/hu/tartalom/tamop425/2011_0001_519_42498_2/ch10s06.html letöltve:2018.06. 10

Behrendt, M., \& Franklin, T. (2014). A review of research on school field trips and their value in education. International Journal of Environmental \& Science Education, (9), 235-245.

Cserné Adermann G. (2006). A felnőttek tanulásának, tanításának új, korszerű módszerei az élethosszig tartó tanulás aspektusából. In Koltai D. \& Lada L. (szerk.), Az Andragógia korszerü eszközeiről és módszereiről (pp. 85-102). Budapest, Magyarország: Nemzeti Felnőttképzési Intézet.

Chikán, A. (2017). Vállalatgazdaságtan. Budapest, Magyarország: Budapesti Corvinus Egyetem.

Demeter K., Gelei A., Jenei I., \& Nagy J. (2009). Tevékenységmenedzsment. Budapest, Magyarország: Aula Kiadó Kft.

Derwik, P., \& Hellström, D. (2017). Competence in supply chain management: A systematic review. Supply Chain Management: An International Journal, 22(2), 200-218. letöltve: 2019.05.10 https://doi.org/10.1108/ SCM-09-2016-0324

Derwik, P., Hellström, D., \& Karlsson, S. (2016). Manager competences in logistics and supply chain practice. Journal of Business Research, 69(11), 4820-4825. letöltve: 2019.05.10 https://doi.org/10.1016/j.jbusres.2016.04.037

Dinnyés J., Rakaczkiné Tóth K., \& Lada L. (2001). Felnőttképzés. Gödöllö, Magyarország: Szent István Egyetem.

Falus I., \& Ollé J. (2008). Az empirikus kutatások gyakorlata. Budapest, Magyarország: Nemzeti Tankönyvkiadó.

Felnöttoktatási és képzési lexikon (2002): Budapest, Magyarország: MPT-OKI Kiadó-Szaktudás Kiadóház.

Flöthmann, C., \& Hoberg, K. (2017). Career patterns of supply chain executives: An optimal matching analysis. Journal of Business Logistics, 38(1), 35-54. letöltve: $2019.05 .10 \mathrm{https} / / /$ doi.org/10.1111/jbl.12150

Gibson, B., Gibson, M., \& Rutner, S. (1998). Careers in logistics. Oak Brook, IL: Council of Logistics Management. 
Hoberg, K., Alicke, K., Flöthmann, C., \& Lundin, J. (2014). The DNA of Supply Chain Executives. Supply Chain Management Review, 18(6), 36.

Juhász M. (2004). A ,,soft-skillek” szerepe a munkahelyi viselkedésben. Munkaügyi Szemle, (11).

Kagan, S. - Kagan, M. (2010). Kagan Cooperative Learning. Budapest, Magyarország: Önkonet Kiadó.

Karcsics É. (2012). Vezetőkkel szemben támasztott munkaerő-piaci kompetenciaelvárások a Heti Világgazdaság és a The Economist álláshirdetéseinek elemzése alapján. Vezetéstudomány, 53(1), 31-44.

Kazainé Ónodi A. (2015). Szituációs játékok alkalmazásának lehetőségei és korlátai az egyetemi oktatásban. In Rajnai Z. et al. (Eds.), Tanulmánykötet a 6. BáthoryBrassai nemzetközi konferencia elöadásaiból (2. kötet, pp. 82-90). Budapest, Magyarország: Óbudai Egyetem.

Keller, K. (ed.) (1999). The growth and development of logistics personnel. Oak Brook, Il: Council of Logistics Management.

KSH (2018): Ipari termelés növekedése, Gyorstájékoztató, Ipar, 2018. április. letöltve: 2018.10.01 http://www.ksh. hu/docs/hun/xftp/gyor/ipa/ipa1804.html

Losonci, D., Kása, R., Szántó, R., \& Lénárd, E. (2018). Managers'competences in lean production context. In Preprints of the Twentieth international working seminar on production economics. Innsbruck, Austria: ISIR Summer School.

Lutz, H., \& Birou, L. (2013). Logistics education: A look at the current state of the art and science. Supply Chain Management: An International Journal, 18(4), 455467.

M. Nádasi M. (2003). Projektoktatás. Budapest, Magyarország: Gondolat Kiadói Kör.

McKinnon, A. C., Hoberg, K., Petersen, M., \& Busch, C. (2017). Assessing and improving countries' logistics skills and training, In Digitalization in Maritime and Sustainable Logistics, Proceedings of the Hamburg International Conference of Logistics (HICL), letöltve: 2019. 05. 10 forrás http://tubdok.tub.tuhh.de/handle/11420/1489

Mihalkovné Szakács K. (2014). Vállalkozási ismeretek oktatása vs. vállalkozói kompetenciák fejlesztése. Vezetéstudomány, 45(10), 49-57.
Murphy, P.R., \& Poist, Jr., R.F. (1991). Skill requirements of seniorlevel logisticians: Practitioner perspectives. International Journal of Physical Distribution \& Logistics Management, 21(3), 3-14. https://doi. org/10.1108/09600039110004025

Myers, M.B., Griffith, D.A., Daugherty, P.J., \& Lusch, R.F. (2004). Maximizing the human capital equation in logistics: Education, experience, and skills. Journal of Business Logistics, 25(1), 211-232.

Nagy J. (2000). XXI. század és nevelés. Budapest, Magyarország: Osiris Kiadó.

Nissen, P., \& Iden, U. (1999). Moderátoriskola. Budapest, Magyarország: Müszaki Könyvkiadó.

Nyíri S. (2006). A logisztika kompetencia-elvárásai és azok oktatási vonatkozásai (Diplomadolgozat). BCE, GTK, Vállalatgazdaságtan Intézet, Budapest, Magyarország.

Pató Gáborné Szücs B. (2006). Kompetenciák, feladatok logisztikai rendszerekben (Competences, tasks in logistics systems) (Doktori (PhD) értekezés). Pannon Egyetem, Pécs, Magyarország.

Sauber, M.H., McSurely, H.B., \& Rao Tummala, V.M. (2008):: Developing supply chain management program: A competency model. Quality Assurance in Education, 16(4), 375-391.

Takács S., Németh M., Juhászné Klér A., \& Toarniczky A. (2017). Az egyetem melletti munkavégzés segítő és gátló tényezői diákszemmel: Kérdőíves felmérés a BCE, BGE és BME mesterszakos hallgatói körében. Vezetéstudomány, 48(3), 39-55.

Tari A. (2010). Y generáció. Budapest, Magyarország: Jaffa Kiadó

Tari A. (2011). Z generáció. Budapest, Magyarország: Tericum Kiadó.

Thai, V. V., Cahoon, S., \& Tran, H. T. (2011). Skill requirements for logistics professionals: findings and implications. Asia Pacific Journal of Marketing and Logistics, 23(4), 553-574. letöltve: 2019.05.10 https://doi. org/10.1108/13555851111165084

van Hoek, R. I. (2001). Logistics education: Achieving market and research driven skill development. International Journal of Physical Distribution \& Logistics Management, 31(7/8), 505-519. 
Melléklet

1. Patóné (2006) . alapján elvárt általános kompetenciák a logisztika egyes területein

\begin{tabular}{|c|c|c|c|c|c|c|}
\hline \multicolumn{7}{|c|}{ Patóné-féle kompetenciák } \\
\hline & Kompetenciák/Területek & Beszerzés & Raktározás & Disztribúció & $\begin{array}{l}\text { Vállallati } \\
\text { átfogó } \\
\text { logisztika }\end{array}$ & Összesen \\
\hline 1 & $\begin{array}{l}\text { Csapatban történő } \\
\text { munkavégzés }\end{array}$ & $\mathrm{x}$ & $\mathrm{x}$ & $\mathrm{x}$ & $\mathrm{x}$ & 4 \\
\hline 2 & Együttmüködési képesség & $\mathrm{x}$ & $\mathrm{x}$ & $\mathrm{x}$ & $\mathrm{x}$ & 4 \\
\hline 3 & Kapcsolattartó képesség & $\mathrm{x}$ & $\mathrm{x}$ & $\mathrm{x}$ & $\mathrm{x}$ & 4 \\
\hline 4 & Kommunikációs készség & $\mathrm{x}$ & $\mathrm{x}$ & $\mathrm{x}$ & $\mathrm{x}$ & 4 \\
\hline 5 & Szervező készség & $\mathrm{x}$ & $\mathrm{x}$ & $\mathrm{x}$ & $\mathrm{x}$ & 4 \\
\hline 6 & Diplomáciai készség & & $\mathrm{x}$ & $\mathrm{x}$ & $\mathrm{x}$ & 3 \\
\hline 7 & Döntési képesség & $\mathrm{x}$ & $\mathrm{x}$ & & $\mathrm{x}$ & 3 \\
\hline 8 & Elemző készség & $\mathrm{x}$ & $\mathrm{x}$ & & $\mathrm{x}$ & 3 \\
\hline 9 & Eredményorientáltság & $\mathrm{x}$ & $\mathrm{x}$ & & $\mathrm{x}$ & 3 \\
\hline 10 & $\begin{array}{l}\text { Folyamatokban/ } \\
\text { rendszerekben való } \\
\text { gondolkodási képesség }\end{array}$ & $\mathrm{x}$ & $\mathrm{x}$ & $\mathrm{x}$ & & 3 \\
\hline 11 & Kapcsolatteremtő képesség & $\mathrm{x}$ & $\mathrm{x}$ & & $\mathrm{x}$ & 3 \\
\hline 12 & Pontosság & $\mathrm{x}$ & $\mathrm{X}$ & & $\mathrm{x}$ & 3 \\
\hline 13 & Precizitás & $\mathrm{x}$ & $\mathrm{x}$ & & $\mathrm{x}$ & 3 \\
\hline 14 & $\begin{array}{l}\text { Problémamegoldó } \\
\text { képesség }\end{array}$ & $\mathrm{x}$ & $\mathrm{x}$ & & $\mathrm{x}$ & 3 \\
\hline 15 & Stressztürö képesség & $\mathrm{x}$ & $\mathrm{x}$ & & $\mathrm{x}$ & 3 \\
\hline 16 & Terhelhetőség & $\mathrm{x}$ & $\mathrm{x}$ & & $\mathrm{x}$ & 3 \\
\hline 17 & Vezetői képesség & $\mathrm{x}$ & $\mathrm{x}$ & & $\mathrm{x}$ & 3 \\
\hline
\end{tabular}

2. Mississippi eredmények általános kompetenciák szerint

\begin{tabular}{|c|c|c|c|c|c|c|c|}
\hline \multicolumn{8}{|c|}{ Mississippi kompetenciák területenként } \\
\hline & Kompetenciák/Területek & Beszerzés & Raktározás & Termelés & Disztribúció & $\begin{array}{l}\text { Vállallati } \\
\text { átfogó } \\
\text { logisztika }\end{array}$ & Összesen \\
\hline 1 & Kommunikáció & $\mathrm{x}$ & $\mathrm{x}$ & $\mathrm{x}$ & $\mathrm{x}$ & $\mathrm{x}$ & 5 \\
\hline 2 & Ellenőrzés & & $\mathrm{x}$ & $\mathrm{x}$ & $\mathrm{x}$ & $\mathrm{x}$ & 4 \\
\hline 3 & Hatékony döntéshozás & & $\mathrm{x}$ & $\mathrm{x}$ & $\mathrm{x}$ & $\mathrm{x}$ & 4 \\
\hline 4 & Motiváció & & $\mathrm{x}$ & $\mathrm{x}$ & & $\mathrm{x}$ & 3 \\
\hline 5 & Fejlesztés & & & $\mathrm{x}$ & $\mathrm{x}$ & $\mathrm{x}$ & 3 \\
\hline 6 & Időgazdálkodás & & $\mathrm{x}$ & $\mathrm{x}$ & $\mathrm{x}$ & & 3 \\
\hline 7 & Prezentáció & & $\mathrm{x}$ & & & $\mathrm{x}$ & 2 \\
\hline 8 & Stressz-, konfliktuskezelés & $\mathrm{x}$ & & & & $\mathrm{x}$ & 2 \\
\hline 9 & Szervezés & & $\mathrm{x}$ & & & $\mathrm{x}$ & 2 \\
\hline 10 & Kiválasztás, toborzás & & & & $\mathrm{x}$ & $\mathrm{x}$ & 2 \\
\hline 11 & Betanítás, oktatás & & $\mathrm{x}$ & & $\mathrm{x}$ & & 2 \\
\hline
\end{tabular}

